\title{
Development of Educational Game Media Based on Problem Based Learning in German Language in the First Grade Senior High School Students SMA Negeri 1 Sibolga
}

\author{
Syahraini Marbun \\ Universitas Negeri Medan, Indonesia \\ syahrainimarbun@gmail.com
}

\begin{abstract}
This study aims to: (1) determine the feasibility of problem-based learning educational game media in German language learning (2) to determine the effectiveness of using problem-based learning-based educational game media on German language material. This type of research is development research using the ASSURE product development model and combined with the Dick and Carey learning design model. This research was conducted on class $X$ students at senior high school SMA Negeri 1 Sibolga. The method used in this research is a quasi-experimental method. The research sample consisted of 60 students consisting of 30 students as an experimental class who were taught using educational game media based on problem based learning and 30 students as a control class who were taught using youtube-based learning media. The results of hypothesis testing prove that there is a significant difference between the learning outcomes of students who are taught about self-introduction in German using problem-based educational game learning media and students who are taught using YouTube-based learning media. This is shown by the data acquisition, namely tcount $=11.27$ while ttable $=1.695$, at a significant level of 0.05 through interpolation ttable 1.695. It is concluded that the effectiveness of German language learning using problem-based educational game learning media is higher than using Youtube-based learning media.
\end{abstract}

Keywords educational games; youtube; German learning outcomes

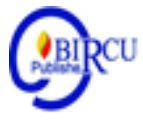

\section{Introduction}

In its development, the term education means guidance or assistance given to children by adults consciously and responsibly. In the world of education, the concept of lifelong education (long life education) has grown, which means that education lasts until death, that is, education lasts a lifetime at any time as long as there is environmental influence (Sagala, 2009: 2). Humans as social beings in everyday life need language as a tool to convey thoughts, feelings and desires from one person to another or from group to other group (Tantawi, 2014: 32). Language is one of the basic and natural abilities bestowed on mankind. Language is one of the gifts (property) that is very biologically attached to humans. Almost all human activities require language. Without language, it is impossible for mankind to have a culture or civilization which includes religion, science and technology.

The factors that play a big role in learning foreign languages are psychological factors and social factors. The psychological factor in question is an intellectual process that involves understanding grammatical structures and their rules, memory which is very 
important in learning, and motor skills that include the use of speech tools to produce sounds in a foreign language. Social factors in language learning take into account the natural situation and situations in the classroom. The development of education in Indonesia is marked by the number of educational institutions that include foreign languages in learning materials. According to Santoso (2014: 9), mastery of foreign languages is needed, for several reasons. First, mastery of foreign languages is an entry point to enter a globalized world community (globalization). Second, as a means to absorb knowledge that is developing in other countries and vice versa as a medium for spreading knowledge that is developing in Indonesia outside.

There are several foreign languages taught in Senior High / Vocational Schools, one of which is German. Learning German is one of the elective subjects for foreign languages which aims to enable students to communicate in the language they are learning and be able to compete in the international world with various language backgrounds. In addition, German plays an important role in the development of the tourism industry in Indonesia (Herlina, J.P.H., 2020). Through observations made at SMA Negeri 1 Sibolga, researchers found various things related to the learning process. This observation was carried out with a German teacher. The information obtained shows that students tend to be less interested in learning. In addition, it is known that there are still many students who have difficulty learning German. The teacher is still the center of learning and students are less active in learning. Based on the results of interviews with several students as well, it was found that students considered German lessons to be subjects that were difficult to master, such as proper pronunciation, German vocabulary, and the use of correct sentence structures. In addition, their interest in learning and interest in German is also lacking.

Therefore, we need an appropriate effort to solve problems in learning German. One effort that can be made to improve student learning outcomes in German is to use learning media combined with problem-based learning based educational games. Through the learning media of problem-based learning games, it is expected that student learning outcomes will increase and can create meaningful learning outcomes. Good teaching objectives not only highlight theoretical achievements and instant knowledge, but also meaningful learning outcomes and positive transformations in student behavior (Dian et al., 2020).

Cheng and Su (2012) in their research entitled "A Game-Based Learning System for Improving Student's Learning Effectiveness in a System Analysis Course" states that game-based learning combined with educational and information technology in learning can increase students' self-efficacy, independent learning, there is continuous interaction and feedback so as to increase student interest and motivation. Therefore, game-based learning can achieve learning objectives effectively. According to research by Cojocariu and Boghiana (2014) entitled "Teaching the Relevance of Game-Based Learning to Preschool and Primary Teachers" found that game-based learning can create positive attitudes, improve memory skills and help students build their own learning atmosphere. Kinder and Kurz (2018) in their research entitled "Gaming Strategies in Nursing Education" stated that there were significant differences in results between the control group and the experimental group. The results showed that the experimental group who used games in learning had higher test scores than the control group.

Based on the above statement, it can show that games as a learning medium can be a solution in improving student learning outcomes. Researchers try to develop a learning media for problem-based learning games using a laptop or android which can be used as an alternative solution related to the problems faced by students in the German learning 
process. Given that most students like a game or game, especially on Android, this media tries to make an educational game as an interactive learning medium for learning German.

\section{Review of Literatures}

Since birth, humans have experienced so much learning. That means that learning activities are very familiar with human life. Muijs, Daniel and David Reynolds (2008: 14), the concept of learning according to behavorism experts is something people do in response to external stimuli. Klein, Stephen (2002: 2) defines Learning as an experiential process resulting in a relatively permanent change in behavior that cannot be explained by temporary states, maturation, or innate response tendencies. Anderson (2000: 4) argues that Learning is the process by which long-lasting changes occur in behavioral potential as a result of experience. Based on some of the definitions above, the researcher concludes that learning is a process of one's business or activity to obtain behavioral changes based on experience and training in their interactions with the environment.

Learning is an activity that makes a person or students learn. Through this activity, students gain knowledge with the help of the teacher or by themselves. This is in line with the opinion of Rombepajung (1988) which states that learning is an effort to acquire new subjects or skills through a lesson or teaching. There are four competencies taught in learning German, namely listening skills (Hören), reading skills (Lesen), speaking skills (Sprechen), writing skills (Schreiben). The four competences of the German language must be supported by good grammar mastery (Structural) and vocabulary mastery (Wortschatz) because all of these competencies are related to one another.

The learning process using media is one of the factors that determines the success of learning. According to Smaldino (2011), the form of media from an intermediary (medium) is a means of communication. Derived from the Latin medium (intermediate), this term refers to anything that carries information between a source and a receiver. Gerlach and Ely (1971) argue that broadly media are humans, materials or events that build conditions that make students acquire knowledge, skills and attitudes.

Currently, learning media have been developed in various forms such as games. The games used in the teaching and learning process and are often used in the world of education are educational games. Clark \& Mayer (2011) defines educational games as a form of play designed to help learners achieve certain learning goals and at the same time provide motivation. Educational games have the aim of increasing student interest in learning in accordance with the material provided by the teacher by playing games, so that students feel happy and not boring (Maulidta, 2019). Educational games can encourage students to learn actively and creatively through some of the challenges given. Sutopo (2012) explains that the use of games in learning can make learning more relaxed and can stimulate students to learn to be more active in solving problems. Through educational games, the learning atmosphere becomes more interesting, considering that most students nowadays often take the time to play games on computers or Androids. Educational games are superior in several aspects when compared to conventional learning methods. One significant advantage according to Clark (2006) is the existence of animation that can improve memory so that children can store subject matter for a longer time than conventional teaching methods. Thus the development of educational games as learning media is expected to provide a pleasant atmosphere in the learning process.

The theory that underlies Problem Based Learning is the theory of Vygotsky, Bruner and Dewey. Vygotsky's theory emphasizes the interaction between internal and external aspects of learning and emphasizes the social environment of learning. Vygotsky (1978) 
explains that learning occurs when students work on tasks that have not been studied but these tasks are still within their reach or those tasks are in their Zone of Proximal Development (ZPD). According to Dewey (1938) the problem is a stimulus to think. These problems can improve students' higher order thinking skills which includes analytical thinking skills. Analytical thinking skills include students' skills in applying logical thinking to collect and analyze information, design and test solutions to problems, and formulate plans (Arnold \& Wade, 2015). Analytical thinking is useful for adapting and modifying information and it includes collaboration that is useful in everyday life (Pennycook, Fugelsang, \& Koehler, 2015). Analytical thinking is very important for the professional success of students in the future (Eckman \& Frey, 2005). Bruner (1975) proposes a cognitive instructional model of learning theory known as discovery learning, which is learning through one's own experience, trying to find solutions to problems and the knowledge that accompanies them, resulting in truly meaningful knowledge. An important concept of learning theory expressed by Bruner is scaffolding. Bruner provides scaffolding as a process where a student is helped to solve certain problems beyond his developmental capacity through the help of a teacher or other person who has more abilities.

A learning model has a syntax or sequence or stages of learning activities that are termed phases that describe how the model is in practice, for example how to start a lesson. According to Arends (2008: 57), the syntax for the Problem Based Learning model begins with the introduction of problems to students. Furthermore, students are organized in several groups to carry out problem solving discussions. The results of the analysis were then presented to other groups. At the end of the lesson the teacher clarifies the results of the students' investigation.

\section{Research Methods}

In developing educational game learning media in German subjects, the ASSURE development model is used. ASSURE development model (Analyze Learners; State Objectives, Select Methods, Media and Materials; Utilize Media and Materials; Require Learner Participation, and Evaluate and Revise). Furthermore, validating 3 instruments to each validator consisting of experts consisting of learning design experts, media experts, and material experts, Then the results obtained were tested again on 60 students consisting of 2 classes, experimental class and control class. The experimental class consisted of 20 students using the educational game media based on problem based learning and the control class consisted of 20 students using youtube media.

\section{Discussion}

Based on the process of implementing research and development, the results of research were carried out in the following ways. This research stage uses the ASSURE development stage (Analyze Learners; State Objectives, Select Methods, Media and Materials; Utilize Media and Materials; Require Learner Participation, and Evaluate and Revise).

\subsection{Analyze Learners}

The first step is to analyze the characteristics of the learner. Media and technology are said to be effective if there is a match between the characteristics of the learner and the method of the media and the characteristics of the learner. With learner analysis will assist 
in the recovery of appropriate learning methods and media. When students are learning a new concept for the first time, it requires direct and concrete learning experiences such as field trips or role-playing exercises. If in learning German, students are introduced to the history or culture of the German state, or they can explain the ease of obtaining scholarships to continue their studies in Germany through a short video. An important component of designing lessons is to identify the specific competencies of students. We can do this through informal means or formal means. By analyzing the abilities that students already have, teachers can choose the appropriate method and media.

\subsection{State Objectives}

The next step is to formulate learning objectives as specific as possible. These objectives are elaborated from the syllabus and textbooks according to the curriculum. Learning objectives are formulated to obtain cognitive, psychomotor and affective skills from students. Cognitive domain, learning includes the composition of intellectual abilities which are classified as verbal / visual information or intellectual skills. Intellectual skills invite students to respond to certain situations including remembering or mentioning facts. Intellectual skills encourage students to think. In the affective domain involves feelings and values. Affective goals, for example, to stimulate interest in German lessons in schools, increase social care among students. Whereas in the psychomotor domain, the assessment of learning outcomes is carried out using a test tool in the form of actions that are assessed based on teacher observations. Learning outcomes in the psychomotor domain include German language practice such as dialogue or role-playing / German drama. Interpersonal skills are people-centered skills that need to relate to other people effectively.

\subsection{Select Methods, Media and Materials}

In determining or choosing a method there is no single method that is the best for all learning activities. For a learning activity it is necessary to combine methods with one another. In this case the researcher uses a simulation method to increase attention and generate interest at the beginning of the lesson, then uses a demonstration to display new information, then provides practice speaking German to practice these new skills. The media used is a problem-based learning based educational game media that has been designed to be a quiz game in the form of images and videos that are inserted into an application called Kahoot. In the stages of making images and videos, they are made in such a way as to produce an attractive appearance. The material presented comes from the book Deutsch ist Einfach and the internet.

\subsection{Utilize Media and Materials}

At this stage the media and learning materials are validated by several validation experts so as to produce comments and suggestions from experts on the media and material then revisions are made according to suggestions and comments for further limited testing of students.

\subsection{Require Learner Participation}

The results of the educational game media based on problem-based learning that have been validated by the experts are then revised and tested on a limited basis with 9 representatives of class X MIA 1 and X MIA 2 students. 


\subsection{Evaluate and Revise}

This stage is the stage of media revision after getting the results of a limited trial according to suggestions and comments. After being revised and in accordance with the feasibility category of learning media, this problem-based learning game was tested on German language teachers at SMA Negeri 1 Sibolga and students as users of learning media.

The results of studies by material and design experts and media experts in each aspect of the overall assessment are determined by the average score in the respective categories. The results of the study were then analyzed to determine whether the learning media was developed or not. The average percentage of results from research material experts, instructional design experts and media experts will be explained as follows:

Table 1. Summary of Product Eligibility Results that have been Validated by Experts and Trials

\begin{tabular}{|c|c|c|c|}
\hline No & Categorization & $\begin{array}{l}\text { The percentage of } \\
\text { average score }\end{array}$ & Crite ria \\
\hline 1. & Learning Design Validation & $90 \%$ & Very Worth it \\
\hline 2. & Media Validation & $80 \%$ & Very Worth it \\
\hline 3. & Material Validation & $95,71 \%$ & Very Worth it \\
\hline 4. & Student test & $92,72 \%$ & Very Worth it \\
\hline & Average & $\mathbf{8 9 , 7 5 \%}$ & Very Worth it \\
\hline
\end{tabular}

Based on the table above, it can be concluded that the Educational Game Learning Media Based on Problem Based Learning in the German language subject is proven to be very feasible because it has passed the material experts, design experts, media experts, the student test results are declared "Very Feasible".

Learning Media for Problem Based Learning Educational Games in German as well as validation and testing shows a percentage value of $90, \%$ in the validation of learning designs, $80 \%$ in media validation, $95.71 \%$ in material validation, $92.72 \%$ in student trials . Overall, the average percentage is included in the "Very Appropriate" category, which means that the use of Problem Based Learning Educational Games in German subjects meets the needs of students. From the results of research data processing, there is an average result of learning German after using Problem-Based Learning Educational Games media in class X Senior High School SMA Negeri 1 Sibolga.

\section{Conclusion}

Based on the results of the research and what has been done, the following conclusions are given: (1) Producing problem-based learning educational games is indispensable in supporting the German language learning process. The application of problem-based learning educational games can foster student enthusiasm for learning and make it easier for teachers to deliver subject matter. The production process of problembased learning based educational games begins with conducting research and gathering information, analyzing student needs, formulating subject matter items, designing products, design validation, revisions, and product testing. (2) Educational games based on problem based learning are effectively used in the learning process and can improve student learning outcomes. This can be seen from the results of the hypothesis test, $t_{\text {table }}=$ 1.695 which is calculated using the degree of confidence 0.05 and $\mathrm{dk}=30$, while the $t_{\text {count }}$ obtained is 11.27 , then $t_{\text {count }}>t_{\text {table }},=11.27>1.695$. Based on these results it can be 
concluded that there are differences in the effectiveness of learning before and after using problem-based learning based educational games.

Based on the above conclusions, from this study some suggestions can be made as follows: (1) For teachers, the development of problem-based learning educational games with self-introduction material in German can be developed on other materials with the same characteristics. (2) For other researchers, this research can be continued in a wider population for a longer period of time so that the results obtained are maximized.

\section{References}

Anderson, L.W., \& Krathwohl, D.R. (2001). A Taxonomy for Learning, Teaching, and Assesing: A Revision of Bloom's Taxonomy of Educatioanl Objectives. New York: Addison Wesley Longman, Inc.

Arends, Richard. (2008). Learning to Teach. Penerjemah: Helly Prajitno \& Sri Mulyani. New York: McGraw Hill Company

Arnold, R. D., \& Wade, J. P. (2015). A Definition of Systems Thinking: A Systems Approach. Procedia Computer Science, 44(1), 669 - 678.

Bruner,J.(1975) From communication to language. A psychological perspective, Cognition.

Cheng, C.H., \& Su, C.H. (2012). A Game-based learning system for improving student's learning effectiveness in system analysis course. Procedia-Social and Behavioral Science, 31(1), 669-675. doi.org/10.1016/j.sbspro.2011.12.122.

Clark, D. (2006). Games and e-learning. Diakses dari www.caspianlearning.co.uk/Whtpcaspian-games_1.1.pdf

Clark, R. C., \& Mayer, R. E. (2011). E-learning and the science of instruction: Proven guidelines for consumers and designers of multimedia learning. San Francisco USA: Pfeiffer

Cojocariu, V.M., \& Boghiana, I. (2014). Teaching the Relevance of Game-Based Learning to Preschool and Primary Teachers. Procedia-Social and Behavioral Sciences, 142 (1),640-646. doi.org/10.1016/j.sbspro.2014.07.679.

Dewey, J. (1938) Logic. The Theory of Enquiry (New York, Henry Holt and Company, Inc.).

Dian, A.P., Mahfud., Hermawan, C. \& Susanti, H.D. 2020. Nasionalism: Character Education Orientation in Learning Development. Budapest International Research and Critics Institute-Journal (BIRCI-Journal). 3(4):4026-4034

Eckman, M., \& Frey, D. K. (2005). Using the WebCT NAFTA Program to Promote Analytical Thinking and Global Awareness Competencies Through a Team Approach. International Textile \& Apparel Association, 23(4), 278-289.

Gerlach \& Ely (1971). Teaching \& Media: A Systematic Approach. Second Edition, by V.S. Gerlach \& Ely (1980), Boston, MA: Allyn and Bacon.

Herlina, J.P.H. 2020. The Importance of German Language Skills in the Tourism Sector. Britain International of Linguistics, Arts andEducation (BIoLAE) Journal. 2 (3): 817--824

Kinder, F.D \& Kurz, J.M. (2018). Gaming Strategies in Nursing Education. Teaching and Learning in Nursing, 13, 212-214. doi.org/10.1016/j.teln.2018.05.001.

Klein, Stephen B. 2002. Learning: Principles and Applications. Fourth Edition. New York: McGraw Hill

Maulidta, N.A. (2019). Perancangan Media Pembelajaran Game Edukasi Untuk Meningkatkan Pemahaman Mata Pelajaran Jaringan Komputer. Program Studi 
Pendidikan Teknik Informatika Fakultas Keguruan Dan Ilmu Pendidikan Universitas Muhammadiyah Surakarta

Muijs, Daniel dan David Reynolds. 2008. Effective Teaching Evidence and Practice. Second Edition. London: Sage Publication.

Pennycook, G., Fugelsang, J. A., \& Koehler, D. J. (2015). Everyday Consequences of Analytic Thinking. Current Directions in Psychological, 24(6), 425-432.

Rombepajung, J.P. (1988). Pengajaran dan Pembelajaran Bahasa Asing. Jakarta: Departemen Pendidikan dan Kebudayaan Direktorat Jenderal Pendidikan Tinggi Proyek Pengembangan Lembaga Pendidikan Tenaga Kependidikan.

Sagala, S. (2009). Konsep dan Makna Pembelajaran Untuk Membantu Memecahkan Problematika Belajar dan Mengajar. Bandung: Alfabeta

Santoso, I. (2014). Pembelajaran Bahasa Asing Di Indonesia: Antara Globalisasi Dan Hegemoni. Bahasa \& Sastra, 14(1), http://ejournal.upi.edu/index.php/BS_JPBSP/article/view/696

Smaldino, Sharon. E., Lowther, Deboran. L., Russel, James.D. (2011). Teknologi Pembelajaran dan Media untuk Belajar. (Alih Bahasa: Arif Rahman). Jakarta: KENCANA.

Sutopo, A. H. (2012). Teknologi Informasi dan Komunikasi dalam Pendidikan. Yogyakarta: Graha Ilmu.

Tantawi, I. (2014). Terampil Berbahasa Indonesia. Bandung: Citapustaka Media Perintis Vygotsky, L.S. (1978) Mind in Society: the development of higher mental processes (Cambridge, Harvard University Press). 